Accepted for publication in Political Representation: Communities, Ideas and Institutions in Europe (c.1200-c.1690) edited by M Damen, J Haemers and AJ Mann, Later Medievel Europe, 15. Leiden, Brill, pp. 142-160

\title{
Officers of state and representation in the pre-modern Scottish Parliament
}

\section{Alastair J. Mann}

Pre-modern parliamentary historiography's obsession with the two main branches of representative study — the "selection" of individual members of parliament by some electoral process, and the credibility of parliamentary participants from the ranks of a social group or estate - has resulted in limited reflection on officers of state. ${ }^{1}$ It is as if the very condition of crown ministers, not being "public men", ${ }^{2}$ undermines the value of collective or particularized analysis, other than through studies of the ubiquitous great ministers of national history, such as Axel Oxenstierna (1583-1654) of Sweden under Gustavus Adolphus or Cardinal Mazarin (1602-61) of France under Louis XIV. Anachronistically, the others seem but civil servants in a pre-modern setting. In a Scottish parliamentary context this is especially unsatisfactory from both procedural and political perspectives. Scottish historians are to blame themselves, of course. The fact that no monograph of the pre-1707 Scottish parliament was published between 1924 and 1996 confirms what MacDonald describes as a limited "historiographical tradition on which to draw". ${ }^{3}$ Nevertheless, in the last two decades, fresh interest in procedural exploration coupled with a reappraisal of the significance and sophistication of the Scottish parliament provides some foundations for a consideration of Scottish officers of state and their parliament. ${ }^{4}$

\footnotetext{
${ }^{1}$ Most, deliberately or by omission, are unconvinced, see Antonio Marongiu, Medieval Parliaments: A Comparative Study (London, 1968), pp. 223-28; A.R. Myers, Parliaments and Estates in Europe to 1789 (London, 1975), pp. 23-29; Wim Blockmans, "Representation (since the thirteenth century)" in The New Cambridge Medieval History, ed. Christopher Allmand (Cambridge, 1998), 7, pp. 29-64, at 32-34 and 38; Michael A.R Graves, The Parliaments of Early Modern Europe (Harlow, 2001), pp.159-91and David Stasavage, States of Credit: Size, Power and the Development of European Politics (Princeton, 2011), pp. 6165.

${ }^{2}$ David Runciman and Mónica Brito Vieira, Representation (Cambridge, 2008), pp. 3-28, at 19

${ }^{3}$ Robert.S. Rait, The Parliaments of Scotland (Glasgow, 1924); John R. Young, The Scottish Parliament, 1639-1661: A Political and Constitutional Analysis (Edinburgh, 1996); Alan R. MacDonald, "Chancellors, Presidents and Speakers: Presiding Officers in the Scottish Parliament before the Restoration”, Parliamentary History 1 (2010), p. 49

${ }^{4}$ Keith M. Brown and Alastair J. Mann, "Introduction" in The History of the Scottish Parliament. Volume 1: Parliament and Politics in Scotland, 1567-1707, ed. Brown and Mann (Edinburgh, 2005), pp. 1-56; Mann, "House Rules: Parliamentary Procedure" in The History of the Scottish Parliament. Volume 3: Parliament in Context, 1235-1707, ed. Keith M.
} 
King James VI of Scotland (r.1567-1625), later I of England (r.1603-25), declared on the death of his chancellor Sir John Maitland of Thirlstane in 1595, that "he would no more use chancellor or other great men in those his causes, but such as he might convict and were hangable". This reflects James's desire to place his own "new" men, such as Maitland, in the administration of government rather than appointing from the ancient nobility, although it also confirms the precarious position of such "men of business", those who, for example, were so crucial to the management of the English houses of commons and lords. Delivering the crown legislative agenda presented particular political and personal challenges for those involved. Essentially, as the crown's authority over the Scottish estates varied so also did the power of its officers. ${ }^{5}$

Regardless of authority, the specific nature of meetings of the Scottish parliament or of conventions - that alternative gathering which was also a meeting of estates yet summoned with less notice and generally limited to agreeing taxation — impacted on the significance of these officers. ${ }^{6}$ Scotland's pre-1707 parliament was unicameral, like the estates general of France until 1560 or the parliament of Naples, and unlike the bicameral institutions of England, Ireland and Poland. ${ }^{7}$ The common Continental model, where estates sat separately, was visited upon Scotland for a period from the 1560s to 1620 s but was for intermittent

Brown and Alan R. MacDonald (Edinburgh, 2010), pp. 122-56; Keith M. Brown and Roland J, Tanner (eds.), The History of the Scottish Parliament. Volume 2: Parliament and Politics in Scotland, 1235-1560 (Edinburgh, 2004); Alan R. MacDonald. The Burghs and Parliament in Scotland, c.1550-1651 (Aldershot, 2007), esp. chs. 6 and 7, and MacDonald, "Chancellors, Presidents and Speakers", pp. 49-61; but see also E.E.B. Thomson, The Parliament of Scotland, 1690-1702 (Oxford, 1929), pp. $44-51$ and Rait, Parliaments of Scotland, pp. 17374, 198-99, 278-83 after Charles Sanford Terry, The Scottish Parliament: Its Constitution and Procedure, 1603-1707 (Glasgow, 1905), pp. 4-9.

${ }^{5}$ J. Bain et al. (eds.), Calendar of State Papers relating to Scotland and Mary, Queen of Scots, 1547-1602, 13 vols. (Edinburgh, 1898-1969), 12, p.117; Michael A.R. Graves, "The management of the Elizabethan house of commons: the council's 'men of business", Parliamentary History 2 (1983), pp. 11-38; R.C. Munden, "All the privy council being members of this house. A note on constitutional procedure in the house of commons", Parliamentary History 12 (1993), pp. 115-25. Brown and Mann ,'Introduction", p. 11. ${ }^{6}$ For the Scottish Parliament in European context, see John R. Young, "The Scottish parliament in the seventeenth century: European perspectives", in Ships, Guns and Bibles in the North Sea and the Baltic States c. 1350-c. 1700, ed. Allan I. MacInnes, Thomas Riis and Frederik Pederson (East Linton, 2000), pp. 139-72. The Polish sejm also had ordinary and extra-ordinary sessions that roughly equate to Scottish parliaments and conventions, see ibid., p. 171.

${ }^{7}$ For comparisons see Graves, Early Modern Europe, pp. 163-64 and David L. Smith, The Stuart Parliaments, 1603-1689 (London, 1999), pp. 4-5. 
deliberation not voting. The crown ensured deliberative and ad hoc multi-cameralism was abandoned thereafter, other than when it lost control from 1641 to $1651 .{ }^{8}$ Thus in Scotland, even though we may question the effect a single chamber assembly had on managing business as reflected in the activities of house managers, as well as the capacity of such a parliament to be representative, crown-appointed officers of state presided over the whole event. The three or four estates represented the traditional social groups: the clergy, nobles and elected burgh commissioners (town burgesses and merchants), plus elected shire commissioners (barons) introduced in the 1590s, "commissioner" being the term used for elected members.

Although similar to the secret committee of the Swedish riksdag, one unique aspect of the Scottish parliament was the standing committee known as the lords of the articles. ${ }^{9}$ Through this device, which first emerged in the late fourteenth century during a period of crown weakness, proposed legislation was drafted and vetted. From the late sixteenth century, the committee was increasingly seen as the key to crown control of parliamentary business and its existence was a grievance at times of revolutionary politics, as seen in the 1640s when its meetings were suspended by the Covenanters who rebelled against the religious and secular policies of Charles I (r.1625-49) and, though it was reinstated in 1661, in its final abolition at the revolution against James VII and II (r.1685-88) in 1688/89. When active, in the seventeenth century this committee consisted of forty members with equal numbers of each estate added to officers of state. All such officers were also members of the Privy Council in Edinburgh and almost all privy councillors were members of parliament, which was the case before and after the Anglo-Scottish regal union of $1603 .{ }^{10}$ This extended the reach of the "men of business" into both the executive and legislature. In addition, crown control was

\footnotetext{
${ }^{8}$ Alan R. MacDonald, "Deliberative processes in the Scottish parliament before 1639: multicameralism and the lords of the articles", Scottish Historical Review 81 (2002), pp. 23-51. MacDonald traces a tradition of distinct meetings of separate estates dating back to the late fifteenth century, but the extent to which this was fixed procedure or ad hoc is less clear before 1641.

${ }^{9}$ Roland J. Tanner, "The lords of the articles before 1540: a reassessment", Scottish Historical Review 79 (2000), pp. 189-212; MacDonald, "Deliberative processes", pp. 23-51, and Alastair J. Mann, "Inglorious revolution: administrative muddle and constitutional change in the Scottish parliament of William and Mary", Parliamentary History 22 (2003), pp. 121-44.

${ }^{10}$ Analysis of minor crown servants in relation to parliament has yet to be carried out. In the 1614 French estates general, at least a third of its members were reliable crown servants. See G.A. Rothrock, "Officials and king's men: a note on the possibilities of royal control in the estates general", French Historical Studies 2 (1962), pp. 504-10.
} 
emphasized in 1612 when James VI and I reintroduced the sixteenth-century procedure (first recorded in 1525) whereby the estates selected their representatives on the committee but did so by means of instructing bishops to choose a list of nobles, and nobles a list of crownselected bishops, with these two groups coming together to select shire and burgh members. This procedure, which allowed the monarch to provide the episcopate with a preferred list, was objected to from time to time, and especially by the nobility, who protested in 1617 , 1621 and 1633, and ensured that not every crown nominee made it onto the committee. This helps explain the suspension of the committee as part of a remarkable constitutional revolution in 1640/41, which also saw officers of state prevented from sitting in parliament ex officio. ${ }^{11}$ However, crown belief in the value of the lords of the articles is seen in its revival in 1661, accompanied by the return of the 1612 method of selection. ${ }^{12}$ The history, therefore, of officers of state is inextricably linked to that of this committee, although after the latter was abolished the work of the former clearly continued. It became, however, a task beyond the skills of the administrations of King William (r.1689-1702) and Queen Anne (r.1702-14). Such was the difficulty in controlling an Edinburgh parliament driven by a sense of party and grievance that the political crisis soon built to its drastic solution: the Anglo-Scottish parliamentary union of 1707.

Before we consider their role in parliament, we should consider where these offices came from. The shape of Scottish politics and administration was transformed in two main phases, though it took time. The first of these stemmed from the period of Anglo-Normanization in the twelfth and thirteenth centuries, through which positions such as sheriff and justiciar appeared, though some of these posts, sheriffs in particular, were hereditary in the families of the great lords, and royal authority, as much as it existed, was still by the great landowners in their own localities. It was out of this period though that the post of chancellor first appeared c.1123, high steward c.1150, clerk register in the 1280s; and then later secretaries of state in

\footnotetext{
${ }^{11}$ John R. Young, "The Scottish parliament and the covenanting revolution: the emergence of a Scottish commons", in John R. Young (ed.), Celtic Dimensions of the British Civil Wars (Edinburgh, 1997), pp. 164-81.

12 Tanner, "Lords of the articles", pp. 208-9; K.M. Brown et al. (eds), The Records of the Parliaments of Scotland to 1707 (St. Andrews, 2008-15), at http://rps.ac.uk/ [RPS], 1525/7/4. For the minority of James V, see Ken Emond, "The parliament of 1525", in Parliament and Politics in Scotland, 1235-1560, ed. Brown and Tanner, pp.160-78; Vaughan T. Wells, "Constitutional Conflict after the Union of the Crowns: Contention and Continuity in the Parliaments of 1612 and 1621" and John R. Young, "Charles I and the 1633 Parliament" both in Parliament and Politics in Scotland, 1567-1707, ed. Brown and Mann (Edinburgh, 2005), pp. 86-87, 95-97, 120-23.
} 
the 1360s. ${ }^{13}$ There is some evidence from the 1290s that Scotland's political community had followed England in seeking to approve such appointments, though with no more sustained success in the medium term. ${ }^{14}$

After a period in the late fourteenth and early fifteenth centuries when under political pressure the informal overlap between such posts and the royal household was gradually replaced by a more formalized system, a second phase of more centralizing administrative and bureaucratic reform occurred in the renaissance period of the fifteenth and sixteenth centuries. ${ }^{15}$ Fresh ideas about representation and engagement with "new" institutions, courts of justice, merchant guilds, and a greater emphasis on estates in parliament, with the arrival of more educated lay administrators, came together, not of a sudden but based on building trends and the copying of ideas from England and Continental Europe. Taking over the financial role of chamberlains (an ancient and increasingly honorific position), came treasurers and comptrollers from the 1420s, who managed the household and non-household crown expenditure and were merged in 1610; then the legal men, the crown law officer or prosecutor the lord advocate in the 1470s; also two decades later the master of requests, an intermediary between petitions and the Scottish privy council, and in the 1530s the lord president of the court of session, Scotland's highest civil court and then the post of justice general from the 1620s, head of the high court of justiciary, the highest criminal court in the land. This bureaucracy with its associated pensions and privileges was an opportunity for individual preferment and crown patronage.

Some of these "officers" were regarded as "great" and some as "lesser", and this appears especially significant as recorded in the seventeenth-century official parliamentary record -

\footnotetext{
${ }^{13}$ The main sources and for the table below are commissions in RPS, J. Balfour Paul et al. (eds.), Registrum Magni Sigilli Regum Scotorum: Register of the Great Seal of Scotland (Edinburgh, 1882-1914), vols. 2-11 for 1424-1668 and National Records of Scotland [NRS], manuscript registers C.3, Registrum Magni Sigilli Regum Scotorum: Register of the Great Seal of Scotland, vols. 9-16 (1665-1716). The best listing is E.B Fryde, D.E. Greenway, S. Potter and I. Roy (eds.), Handbook of British Chronology (Cambridge, 1997), pp.179-204. For a summary of duties, see Julian Goodare, The Government of Scotland 1560-1625 (Oxford, 2004), pp. 149-72.

${ }^{14}$ David Carpenter, "Scottish Royal Government in the Thirteenth Century from an English Perspective" in New Perspective on Medieval Scotland, ed. Matthew Hammond (Woodbridge, 2013), pp. 117-59, at p. 133.

${ }^{15}$ For resentment at household "servants" restricting access to the court in the 1380s, see John J. McGavin, “Robert III's 'Rough Music': Charivari and Diplomacy in a Medieval Scottish Court”, Scottish Historical Review74 (1995), pp. 144-58.
} 
the "great" were now the chancellor, the treasurer (by then the high treasurer), the lord privy seal (or keeper of the privy seal), lord president of the council (from 1661) and secretary of state (more dependent on the station of office holder) and the "lesser" the clerk register, lord advocate, lord justice clerk, treasurer-depute, master of requests (in parliament 1604-33), comptroller (until 1609), and collector (also until 1609).

What sort of individuals became officers of state in Scotland? Chancellors were mainly clerics from King Alexander I's reign (r.1107-24) in the twelfth century to that of James III (r.1460-88) in the late fifteenth century. Thereafter, however, two out of three were nobles and no clergy were appointed from 1546 to 1634 . Treasurers, from their introduction in the 1420s, were a mixture of clergy and barons (as had been chamberlains in the fourteenth century) but from the 1550 s nobles predominate. The 1540 s and 1550 s were watershed years as much as the Scottish Reformation of 1560 itself: counter-reformation Scotland in the decades before 1560 was of a reforming nature in administration, and even social policy as revealed by Scotland's legislative history. ${ }^{16}$ Secretaries, appearing first in the 1360 s (and at that time clerics), were thereafter barons until the 1450s when clergy appeared, although after the Reformation they vanished to be replaced by a mixture of barons and nobles. Lords privy seal were generally clergy from the 1370 s to the Reformation but thereafter nobles. Justice clerks, who managed the criminal courts, appear in the mid-fourteenth century and were almost all barons and lawyers. Lords president of the court of session were generally clergy before the Reformation, yet legal barons took over thereafter. Since lords advocate were introduced in the 1470s all have been lawyers and barons. Meanwhile, clerks register, the senior government clerk, have, since their introduction in the late thirteenth century, been appointed from the barons with a few clergy, the last of them being the long tenure of Gavin Dunbar, bishop of Aberdeen, a literary cleric who wrote a much admired translation of Virgil's Aeneid, which ended with his death in 1522. The first clerk register to be a noble at the time of appointment was not until 1692 when George Mackenzie, Viscount Tarbat, one of the most remarkable Scottish officers of state in the early modern period, was reappointed.

\footnotetext{
${ }^{16}$ Alastair J. Mann, "The Law of the Person; Parliament and Social Control", in Brown and MacDonald (eds.), Parliament in Context, pp. 186-215.
} 
Table 1: Individual Officers of State c.1600 to 1707: order at appointment ${ }^{17}$

Office

Chancellor:

Secretary

Privy Seal

Treasurer

Lord Advocate

Justice General

Justice Clerk

Total Clergy Nobles Barons Commissions

$\begin{array}{llll}15 & 1 & 12 & 2\end{array}$

Vacant 1681-82. Commission 1689-92

[3nobles]

$25 \quad-\quad 14 \quad 11$

$14 \quad-\quad 13 \quad 1 \quad$ Commission 1689-90 [3 nobles]

$9 \quad-\quad 8$

$1 \quad$ Vacant 1611-13. Commission 1641-51

[nobles/1 baron], 1660-61 [2 nobles],

1667-82 [6 nobles/2 barons], 1686-1707

[11 sep. commissions: 69 nobles/9

barons]

President of Council $15 \quad-\quad 14 \quad 1$

$17 \quad-\quad 2 \quad 15 \quad$ Commission 1689-92[1 noble/4 barons]

$13-\quad-\quad 13$

$14 \quad-\quad 10 \quad 4$

$18 \quad-\quad-\quad 18$

Looking at the seventeenth century specifically (see Table 1), it is clear that the clergy were completely eclipsed, a process begun just before and following the Reformation. The increased Presbyterianism of the Scottish Church from the 1570s saw the dissemination of a "two-kingdom" philosophy which separated the world of man from the world of God, and so

\footnotetext{
${ }^{17}$ See note 13 for sources. These figures exclude commission members. The post of justice general was hereditary until 1628 and that of President of the Privy Council was merged with Lord President of the Court of Session before 1626. When commissions were appointed, one individual was given the right to vote in parliament ex officio. Treasury commissioners were often reappointed, especially 1686-1707.
} 
disapproved of clerical involvement in secular duties, including attending parliament. Even though bishops were returned to their parliamentary status in the early seventeenth century, their position was precarious, being removed from 1638 to 1651 , and finally excluded in 1690. In the previous five years, James VII's increasing reliance on his bishops in privy council and in cabinet committee dovetailed noble anti-clericalism with disproval from the Presbyterian clergy and so the four estates became three. ${ }^{18}$ Indeed, the great offices were for the previous 150 years seen as the preserve of nobles, with the exception of that of secretary where there was a greater tendency to choose a political and personal favourite of the monarch and perhaps someone more able to handle the challenges of the office. The noble domination in the position of justice general, taking over from the more ancient office of justiciar, shows that in the case of law and order, noble involvement was seen as less awkward than with the court of session and the post of advocate, where legal training was required. Over crime, more practical legal control was provided by the lord justice clerk, almost always a lawyer. The secretary of state is an odd case where, in part to mimic the English system started in 1540 of having two secretaries of state, which by 1660 split into Northern and Southern departments, two Scottish secretaries were appointed from 1682 and in the particular circumstances where James, duke of Albany and York, and his older brother Charles II (r.1660-85) needed to appoint two individuals after the retirement of the greatest political Scot of the age, John Maitland, duke of Lauderdale. ${ }^{19}$ This joint responsibility was to hamper smooth administration, especially with the bizarre system in place by early 1693 in which they took command of Scottish affairs on alternate months. The fact that the two incumbents that year - James Johnston and Sir John Dalrymple, Master of Stair — had a simmering hatred for each other hardly helped. As Johnston put it in a letter written soon after his appointment: 'my colleague (Dalrymple) makes bold with [my business], I shall learn to do with his too'. Treasurers were, meanwhile, predominantly nobles, yet the frequent use of commissions reflects concern that responsibility be shared and monitoring be transparent. Commissions were also more widely deployed in 1689 when the revolutionary

\footnotetext{
${ }^{18}$ Alan R. MacDonald, "Ecclesiastical Representation in the Parliament in Post-Reformation Scotland: The Two Kingdoms Theory in Practice", Journal of Ecclesiastical History 50 (1999), pp. 38-61; Alastair J. Mann, James VII: Duke and King of Scots, 1633-1701 (Edinburgh, 2014), p. 172 and "James VII, King of the Articles: Political Management and Parliamentary Failure”, in Brown and Mann, Parliament and Politics, p. 193

${ }^{19}$ Mann, James VII, p. 98
} 
government sought to be as inclusive as possible and to extend patronage widely and conversely to limit the power of individuals and family interests. ${ }^{20}$

Most of these officials had an administrative life outside parliament, but what of their existence within parliament? Officers of state attended parliament as nominees of the crown, and did not attend by right, by summons or by election. The English parliament, if we can draw a parallel there, clearly also included officers of state yet although they held office by royal appointment, a seat in parliament depended on their being elected to the commons, or by summons, if bishop or peer, to the lords. In other words, their appointment did not in any way confer a right to attend parliament and vote. However, for Scotland after appointment an officer of state sat in his particular capacity and not as a member of an estate. Furthermore, if a shire or burgh member was appointed when already elected to the house, he had to relinquish his seat to make way for a fresh by-election. He took his seat thereafter as a crown nominee; for example, in 1684 Sir James Foulis of Colinton relinquished his seat as shire commissioner for Edinburghshire on being made lord justice clerk, and in 1696, when Sir James Ogilvie, the burgh commissioner for Cullen, was appointed secretary of state, the town was given warrant to hold a fresh by-election. The dynastic nature of local politics is confirmed in both cases: Foulis being replaced by his son and, after a brief hiatus, Ogilvie's brother becoming commissioner for Cullen in $1703 .{ }^{21}$

It seems the ex officio right of such officers of state to attend and vote in parliament (supplementing those officers who were peers or prelates) emerged in the course of the fourteenth and fifteenth centuries. This diverse group of "lesser" individuals, lower clergy, adult sons of nobles, lairds or barons, became more common by the reign of King James $\mathrm{V}$ (r.1513-42). In the sederunt (attendance roll) of 1540, six crown officers are listed, including the clerk register and justice clerk. Later, in the parliament of 1567, in the personal reign of Mary, Queen of Scots (r.1561-67), six "great" officers were added to the committee of the articles - the clerk register, justice clerk, lord advocate, treasurer, secretary and lord privy seal. From this period, and after the Reformation, we see emerging a clearly defined and slowly expanding list of "great offices" with ex officio parliamentary membership.

\footnotetext{
${ }^{20}$ NRS, State Papers [SP] 3/1, Johnston to the earl of Tweeddale, chancellor, 18 February, 1693; Letters and State Papers Chiefly Addresses to George, Earl of Melville ... 1689-1691 (Edinburgh, 1843), pp. 340-41; Mann, "Inglorious revolution", pp. 130-31.

${ }^{21}$ RPS , 1685/4/2; 1696/9/17; Margaret D. Young (ed.), The Parliaments of Scotland: Burgh and Shire Commissioners, 2 vols., (Edinburgh, 1992), 1, p. 261, 2, pp. 553-54; Terry, Scottish Parliament, pp. 4-5.
} 
Simultaneously, an end had therefore come, in a voting sense, to the participation of some lesser officers, though from the 1690s some were given special leave to attend as observers and advisors. This group, with dates of admission, included the judge of the admiralty (1693), deputy to the lord admiral, then William Douglas, third duke of Hamilton; the director of chancellery (1698), deputy to the lord chancellor, then Patrick Hume, first earl of Marchmont; and the solicitor general (or royal solicitor) (1705), deputy to the lord advocate, then Sir James Stewart of Goodtrees. ${ }^{22}$ These apparently sensible proposals caused some concern, as we will see. Nevertheless, one of the qualities of the Scottish estates was their willingness to allow non-voting experts to witness proceedings and tender advice when requested, be they military officers, lawyers, diplomats or merchants with specific commercial competence. Benches were also provided for the sons of nobles to observe business with an eye to their future responsibilities.

Entering the seventeenth century, there were limits to the numbers of crown officials the estates would accept as full voting members, however much the administrative machinery of government may have expanded. We can trace the source of this resentment to the previous half century. Michael Graves places great emphasis on attendance levels when it comes to assessing the health of parliamentary cultures. He informs us that from the 1530s attendance improved in the Cortes of Castile, in the Estates of France and in Scotland, but he notes the passing of legislation in Scotland to the 1580s and 1590s over fines for non-attendance as indicative of continuing problems. The suggestion is that James VI, for reasons of royal prestige and the legitimization of his legislative programme, wanted to maximize attendance. In fact, earlier concern over attendance levels and fines for absence in the 1360s, 1420s, early 1500s and 1580s, were repeated in 1641, 1662, 1663, 1689 and 1693, and confirm a collective desire from those attending that all should do their duty, as much as any royal agenda. ${ }^{23}$ Many of these "problem" sessions were well attended, so something else was going on. Firstly, the uncertain land situation caused by the dislocation of the Reformation, and the subsequent Marian Civil War (1567-73) was increased from 1587 when James VI put an Act of Annexation through parliament, taking crown possession of old Church lands which would see the erection of ecclesiastical estates into hereditary temporal lordships. Thus

\footnotetext{
${ }^{22}$ Rait, Parliaments of Scotland, pp. 173-74; 278-9; RPS, 1540/12/6; 1567/4/3; 1693/4/15; 1698/7/14; 1705/6/20; Mann, "House Rules", pp. 138-39.

${ }^{23}$ RPS , 1426/11; A1515/7/1; 1587/7/26; 1641/7/27; 1662/5/6-7; 1663/6/52; 1689/6/18; 1693/4/15; Graves, Early Modern Europe, pp. 180-82.
} 
it became possible over the next 20 years to expand the Scottish peerage - the likes of the earldom of Melrose being created from the lands of Melrose Abbey, for example. By 1625, no less than 21 out of 30 abbeys had become lordships. Secondly, relative peace after years of war also encouraged the political classes into participation in processes of counsel, attendance at court and, with more patronage on offer, involvement in the business of parliaments. Thirdly, also in the 1587 parliament, we see a resolution of the issue of baronial representation. The disused James I (r.1406-37) legislation of 1428, which excused all barons from attending on condition that they elected shire representatives, was finally put into force and adapted. Somewhat like the Argonese Cortes, a division was established between higher nobility and gentry, hidalgos. A representative system of shire elections, adding to those already existing for the towns, was introduced which into the next century would increase the intensity of electoral politics amongst the lower landed, many of whom were closely connected to competitive noble interests. Fourthly, the increase in the size of the peerage from 51 in the 1560 s to over 140 by 1707 — led to greater competition for patronage and positions of influence and power. In addition, James VI's encouragement of a new generation or noblesse de robe fed into the appointment of officers of state as well as into the expanding peerage. The old nobility, like the earls of Crawford, Mar, Huntly and Hamilton, looked on with some anxiety, fearing a lack of influence. Crown-appointed bishops and officers were seen as voting fodder for the crown, whatever the policy. ${ }^{24}$ As a result, anti-clericalism and some anti-government views became more common, in particular from the Anglo-Scottish union of the crowns in 1603, and had some influence on the revolution against Charles I in the late 1630s. Small wonder that both bishops and officers of state found themselves excluded from the parliaments of the Covenanters in the 1640s.

James VI and I was, though, prepared to compromise over his expanding administrative machinery. From 1603, a high commissioner represented the king or queen in parliament when he or she was absent, as was usually the case up to 1707, and this was always a senior noble. It was the high commissioner who was custodian of the crown agenda and, when acts

\footnotetext{
${ }^{24}$ RPS , 1587/7/18; 1428/3/3; 1587/7/143; Keith M. Brown, "Parliament and the Nobility", in Parliament in Context, ed. Brown and MacDonald, pp. 82-92; Jenny Wormald, Court, Kirk and Community, Scotland 1470-1625 (London, 1981), p. 192; Xavier Gil, "Crown and cortes in early modern Aragon: reassessing revisionism", Parliaments, Estates and Representation 13 (1993), pp. 109-22; Brown and Mann, "Introduction", pp. 19-22, 49; Julian Goodare, "The admission of lairds to the Scottish Parliament", English Historical Review 116 (2001), pp. 1103-33.
} 
were given royal assent, carried out the procedure of touching with the royal sceptre the final version of each act, as well as being empowered to adjourn proceedings. Having a senior crown representative, a "viceroy" perhaps, increased the need for supporting bureaucrats. The next in seniority was the president of the parliament, usually the chancellor, as was the case in the English House of Lords. Debate was conducted through him. The chancellor carried out this role before and after 1603, though from 1640 to 1651 the covenanting parliament asserted its right to choose its own "president", and the House of Lords promptly followed suit in 1641. In spite of these heavyweights, from 1617 king and parliament agreed a maximum number of officers of state that were permitted to sit as lords of the articles, the drafting committee - now only eight could be voting members, attending ex officio. King James made this concession but in the full knowledge that the major officers of state would always be members of the committee. ${ }^{25}$

It is notable, though, that not all subsequent controversy concerning officers of state ended at the Restoration of 1660 or the Revolution of 1689, the two traditional procedural watersheds of the century. The Darien disaster, the failed attempt by the Company of Scotland, with the support of the Scottish parliament, to set up a great trading post at Darien near Panama, was reason for further wrangling over the status of officers of state in the house. When the parliamentary arithmetic was looking troublesome for the government in 1700, as the Darien disaster strained relations between crown and the estates, King William proposed the temporary deflowering of his two secretaries of state, making them both able to vote as nobles, and also temporarily the appointment of a third individual as secretary with voting powers. This would have given the crown three votes of support to replace just one, as normally only one secretary of state could vote. The Scottish Presbyterian lawyer and commissioner for Haddington, Sir John Lauder of Fountainhall provides a bitter account of the legal argument which then ensued: "This weare an unpreasidented practise, and the like can never be showen to have been so much as attemted". The plan was dropped to, in Fountainhall's words, "hinder any farder incroachments on the rights of Parliament". ${ }^{26}$

\footnotetext{
${ }^{25}$ RPS, 1617/5/11; 1640/6/4; 1644/6/2; MacDonald, "Chancellors, presidents and speakers", passim; Rait, Parliaments of Scotland, pp. 508-13; Mann, "House Rules”, p. 139. ${ }^{26}$ Analecta Scotica: Collections Illustrative of the Civil, Ecclesiastical and literary History of Scotland, second series (Edinburgh, 1837), pp. 215-17 (LXXX), "Observations by Lord Fountainhall on the Right of a third Secretary of State to sit in the Scotish [sic] Parliament by Virtue of his Office".
} 
A coterie of additional minor officers was also important to the workings of the Scottish parliament. The dempster, a position first recorded in 1430, was tasked with reading out the judicial "dooms" or verdicts of the parliament, and this included high-profile cases of treason which, being a judicial court like the English House of Lords, came within the parliament's competence. The constable, an office held heritably by the Hay family since 1314, was responsible for the outer security of the parliament, and the marischal, an office held heritably by the Keith family since the late twelfth century, maintained order within the house.

However, the official record confirms that these two noble officers were frequently in dispute as to their duties. ${ }^{27}$ Meanwhile, the clerk register was the chief clerk of parliament. He and his undersecretaries, the six clerks of the court of session who also acted as clerks of parliament, recorded decisions and, with the chancellor, controlled the order of business. The clerk register and the lyon king-of-arms shared responsibility for the "fencing of parliament", a procedure where both in turn read out the formula declaring that the high court of parliament was now in session and none should interfere. Both also had responsibility for managing the state opening at the beginning and end of each parliament, the "riding of parliament". Proceedings began with the reading of precedency by the clerk register before the lord lyon, charged with regulating heraldry within the realm, called out the names to launch the equestrian procession. The office of the clerk register also handled requests for extracts of acts, copies of drafts and, finally, printed acts, and it is easy to see why his appointment was political. At times his competence became the subject of controversy when he was a political heavyweight, as was the case with George Mackenzie, Viscount Tarbat, in $1693 .^{28}$

Out of the particular we may get a more precise picture of the generality. A curious example of an efficient officer of state, and one where the ability of the individual shows that not all royal appointments were purely political in nature, was Alexander Seton, earl of Dunfermline

${ }^{27}$ RPS, 1430/54; Terry, Scottish Parliament, pp. 72-6; J.H. Burton et al. (eds.), Registers of the Privy Council of Scotland, first series, 7, p. 221 (July 1606 dispute).

${ }^{28}$ NRS, SP 3/1, Letter Johnston to William Carstares, 19 May 1693; Joseph McCormick (ed.), State Papers and Letters addressed to William Carstares (Edinburgh, 1774), pp. 17881; Mann, "Inglorious Revolution", pp. 140-42; and Mann, "House Rules", 140; Mann, "The Scottish Parliaments: the role of ritual and procession in the pre-1707 parliament and echoes in the new parliament of 1999", in Rituals in Parliament: Political, Anthropological and Historical Perspectives on Europe and the United States, ed. Emma Crew and Marion G. Müller (Frankfurt, 2006), pp. 135-58 and Mann, "Continuity and change: the culture of ritual and procession in the parliaments of Scotland", Parliaments, Estates and Representation 29 (2009), pp. 143-58. 
(1555-1622). Religious policy, always a priority for an enthusiastic reformer like James VI, was awkward for Seton as he was privately a devoted Roman Catholic and was made chancellor in 1604 the year after which we had the gunpowder plot in London and a series of papist scares. In fact, he remained chancellor until his death in 1622. Seton was one of the new breed of noblesse de robe, although the younger son of a peer. He was a qualified lawyer, an advocate in 1577, a lord of session in 1586, lord president of the court of session from 1593 to 1605, and king's high commissioner to parliament from 1612-17, and one of James's key ministers after the union of the crowns. He was an astute political and parliamentary manager and loyal crown servant, yet his personal leanings towards moderation and constitutionalism led him to work against some of his master's policies, including the extension of clerical involvement in government and parliament. His religious experience was a complex cocktail. Having studied at a Jesuit college when abroad, and worshipping there as a Catholic, the events of the Reformation and James's policies convinced him that churchmen should not get too involved in state affairs. He remained loyal to his master but was one of those who could say no. ${ }^{29}$

George Mackenzie of Tarbat (1630-1714), who we have already mentioned, was one of those who also had a long career as an officer and member of parliament, entering parliament in 1661 as commissioner for Ross-shire. Unlike Seton, he was an Episcopalian. Tarbat was a survivor, weak in the details of administration although an astute political operator, as well as a pamphleteer and polymath. He was, indeed, the only individual to hold high office under Charles II, James VII, William and Mary and Queen Anne. Tarbat was a baron who was rewarded for his crown loyalty during the Cromwellian period (c.1651-60) by being made a lord of session, even though he had no legal training. After being dismissed for involvement in various conspiracies to remove Charles II's main manager of Scottish affairs, the duke of Lauderdale, he was allowed back into government circles in 1678 and was soon appointed justice general and in 1681 clerk register and again a lord of session. When James VII came to power in 1685 he was made a peer as Viscount Tarbat. When the revolution came he wavered, was essentially unemployed but was reinstated as clerk register in 1692, resigning from the post in 1696. When Anne succeeded he was made earl of Cromartie and from 1703-

\footnotetext{
${ }^{29}$ Wells, "Contention and continuity", pp. 84-89, 93-95; Oxford Dictionary of National Biography [ODNB], Maurice Lee jun., Alexander Seton (1556-1622): doi:10.1093/ref:odnb/25113; Maurice Lee, Government by Pen: Scotland under James VI and I (Urbana, 1980), pp. 112-54.
} 
4 was her secretary of state, resigning the office to return to the post of justice general, and retiring completely in $1710 .{ }^{30}$

There are, in fact, numerous instances of Tarbat's incompetence as an administrator. In 1693, his reputation for maladministration reached new depths. Not only had he issued an order in the name of parliament, "which order they never gave", concerning a private process, he also had been repeatedly found to have "[falsified] the minutes". The estates were so appalled at his behaviour that "it was only to prevent noise that he was not suspended from his office". Events descended into farce as Tarbat presided over the defective printing of the acts passed that year. He attempted to blame Agnes Campbell, the king's printer, but it was discovered she had worked to his authorized text, had provided proofs to Tarbat's corrector and only began distribution after he approved a bound copy. Officials and members of parliament, including Sir James Stewart, the lord advocate, had noticed various errors including one act not passed being printed and another passed which was not. When Tarbat eventually offered to resign the clerk registry in 1695 it must have been a great relief to those wishing to preserve the operational efficiency of parliament, let alone to his political enemies. ${ }^{31}$ However, Tarbat remained an enigma, his modest administrative abilities being in inverse proportion to his political status.

To complete a religious triumvirate, another interesting case study is the Presbyterian James Johnston (1655-1737). Johnston was the son of Archibald Johnston of Wariston, a leading figure of the covenanting regime from 1638 to 1651 who they appointed clerk register in 1649, a position confirmed again by Oliver Cromwell in 1657. After the execution of his father in 1663 (he had escaped abroad at the Restoration only to be arrested subsequently), James spent his early years in exile in Holland and returned with an Anglo-Dutch outlook in spite of his Scottish roots. When made joint Scottish secretary in 1692, he was an unknown quantity in terms of the business of government or as a potential threat to his co-secretary, Sir John Dalrymple and his interests. It soon became clear that he had his father's taste for hard work, and he set about discovering the condition of parliamentary administration. He was

\footnotetext{
${ }^{30}$ Mann, James VII, pp. 152-60, 207-9; ODNB, Colin Kidd, George Mackenzie (1630-1714): doi:10.1093/ref:odnb/17580.

${ }^{31}$ NRS, Registers of the Privy Council, PC.1/48 fols. 112, 127, 5 September 1693; NRS, SP 3/1, letter James Johnston to William Carstares, 16 May 1693; Carstares State Papers, pp. 170-78, 229-30; James Grant (ed.), Seafield Correspondence from 1685-1708 (Edinburgh, 1912), pp. 113-14, letter Sir James Stewart to Sir James Ogilvie, 7 August 1693; NRS, PC.1/48, fols. 112-13, 3 August 1693.
} 
popular with King William after the revolution and served as joint secretary until 1696, and briefly clerk register in 1704 under Queen Anne. His cousin Bishop Gilbert Burnet described him as having "a great dexterity in managing business" and "of an entire virtue ... and prone to bluntness and honesty", qualities of mixed blessing in the highly charged political atmosphere leading up to 1707 . He was a commoner, not even a knight, and yet he had a profound impact on the procedures of the Scottish parliament. Not only did he tidy up Tarbat's mess, but he presided over a procedural revolution. He encouraged the proliferation of regular session committees, whereby all matters came back to the full house; in 1695, a new procedure where acts were regularly to "lie on the table", enabling a pause in the legislative process for draft acts to be scrutinized; and in 1696 the processing of legislation was further improved by introducing the printing of draft acts and the "Act that no law pass at first reading". This last piece of reform meant that the word "reading" was formalized in Scotland for the first time, and an act was now subject to a four-stage process: first reading, second or further reading, voting and royal assent. ${ }^{32}$ These reforms made parliament more efficient and able to scrutinize, which was, of course, not necessarily what the crown desired.

As officers of state, who did these individuals "represent"? Michael Metcalf in his edited collection of the Swedish riksdag describes the essential criteria for "representation by estates". They must be independent of each other and have a clear role in the "life of the polity". ${ }^{33}$ It is mostly impossible to see officers of state as being unified in any sense beyond crown loyalty, although they clearly expressed political and social priorities within their individual estates, as nobles, as barons, as clergy, and even occasionally as merchants and as lawyers. All of these men were, of course, owners of land and property, some greater than others, and as landowners as well as fathers and sons they were concerned to preserve those aspects of hereditary right and the maintenance of their social status in society, as well as exploring the prospects for advancement and improved personal wealth. The propertied dominated no more or less than in both houses in England. ${ }^{34}$ Family and kin networks were also political glue. However, occasionally they failed to carry out the royal will and we have

${ }^{32}$ H.C. Foxcroft (ed.), A Supplement to Burnet's History of His Own Time (Oxford, 1902), pp. 370-73, 392, 415; RPS, 1695/5/16; 1696/9/44; 1696/9/62; Rait, Parliaments of Scotland, pp. 429-34; Terry, Scottish Parliament, pp. 149-52; Thomson, The Parliament of Scotland, pp. 88-91; Mann, "Inglorious revolution”, pp. 130-42; ODNB, John Young, James Johnston (1655-1737):doi:10.1093/ref:odnb/14941.

${ }^{33}$ Michael Metcalf (ed.), The Riksdag: The History of the Swedish Parliament (Stockholm, 1987), p. 58; Graves, Early Modern Europe, p. 176.

${ }^{34}$ Smith, Stuart Parliaments, pp. 26-27. 
seen in our case studies that in different ways crown officers could act with independence and sometimes out of principle. Two further examples for this were in 1686, when Sir George Mackenzie of Rosehaugh, the lord advocate, was dismissed for his refusal to accept James VII's plans to repeal the penal laws against Scottish Catholics, and in June 1702 when the clerk register Charles Douglas, earl of Selkirk, walked out with 70 other members of the house in support of the protest led by James Douglas, duke for Hamilton, that the first session of parliament under the new Queen Anne was unconstitutionally convened. He too was soon replaced. ${ }^{35}$ Loyalty may have been insisted upon, but a constructive resignation on principle was occasionally a feature of the officer of state in the last century of the Scottish parliament. In this sense, therefore, they certainly had a clear role "in the life of the polity" and it was a more dynamic role than might be expected.

${ }^{35}$ Mann, James VII, 178; Sir John Lauder of Fountainhall, Historical Notices of Scotish [sic] Affairs, 2 vols. (Edinburgh, 1848), 2, p. 723; Daniel Szechi (ed.), 'Scotland's Ruine': Lockhart of Carnwath's Memoirs of the Union (Aberdeen, 1995), pp. 12-14; RPS, 1702/6/3. 